S. Pierce, J. Bellingardi, S. Villa, A. Ferrario, S. Armiraglio, B. E. L. Cerabolini \& R. M. Ceriani

\title{
Seed germination protocols for EU Habitats Directive species from northern Italy
}

\begin{abstract}
Pierce, S., Bellingardi, J., Villa, S., Ferrario, A., Armiraglio, S., Cerabolini, B. E. L. \& Ceriani, R. M.: Seed germination protocols for EU Habitats Directive species from northern Italy. [In Magrini, S. \& Salmeri, C. (eds), Mediterranean plant germination reports - 3]. Fl. Medit. 31: 305-314. 2021. http://dx.doi.org/10.7320/FlMedit31.305

Germination protocols were developed or optimized for six northern-Italian species protected in Annexes II and IV of the European Union Habitats Directive: Linaria tonzigii, Physoplexis comosa, Primula glaucescens, P. spectabilis, Saxifraga tombeanensis and Spiranthes aestivalis. For some species (L. tonzigii, P. glaucescens), seeds collected in 2004 and stored at $-18^{\circ} \mathrm{C}$ were compared with seeds collected 15 years later, and no statistically significant difference was found for final germination percentage (G), suggesting that seed banking is effective. P. spectabilis germinated at a high rate of $\mathrm{G}=95.4 \%$. Spiranthes aestivalis germinated extremely rapidly for an orchid, starting at just $11 \mathrm{~d}(\mathrm{MTG}=17 \mathrm{~d})$, with extremely high rates $(\mathrm{G}=97.1 \%)$.
\end{abstract}

Key words: Linaria tonzigii, Physoplexis comosa, Primula glaucescens, P. spectabilis, Saxifraga tombeanensis, Spiranthes aestivalis.

\section{Introduction}

The Lombardy region of northern Italy hosts a number of angiosperm species recognized by the European Council Directive 42/93/EEC of 21 May 1992 ('on the conservation of natural habitats and of wild fauna and flora') as either 'species of community interest whose conservation requires the designation of special areas of conservation' (Annex II) or 'species of community interest in need of strict protection' (Annex IV). For many of these species, nothing is known about seed germination and propagation requirements.

Here we present germination protocols for six 'Habitats Directive' species currently the object of conservation programmes in Lombardy: Annex II: Linaria tonzigii Lona (Plantaginaceae) and Saxifraga tombeanensis Boiss. ex Engl. (Saxifragaceae); Annex IV: Physoplexis comosa (L.) Schur (Campanulaceae), Primula glaucescens Moretti, P. spectabilis Tratt. (Primulaceae), and Spiranthes aestivalis (Poir.) Rich. (Orchidaceae). 
Of these, L. tonzigii and S. tombeanensis are listed as 'Endangered' in the IUCN Red List (Armiraglio \& al. 2010; Mangili \& Rinaldi 2013), while the other species are 'Least Concern' (Jogan \& al. 2013; Lasen \& al. 2013). All species investigated here are also protected by Lombardy Regional law (n. 10, 31 March 2008) for the 'Flora and small fauna protected in Lombardy'. Specifically, they are listed as grade ' $\mathrm{C} 1$ ' rigorously protected species which cannot be damaged or removed without permission from the Lombardy Regional Government. Furthermore, Annex II species require a collection permit from the 'Ministry of the Ecological Transition' (Ministero della Transizione Ecologica). All material collected and used for the present study was obtained from the wild with collection permit DPN/2D/2004/13650 issued by the Ministry of the Environment to the Lombardy Seed Bank (LSB).

66. Physoplexis comosa (L.) Schur (Campanulaceae) (Fig. 1)

\section{Accession data}

It: Tremosine sul Garda (BS), loc. Passo Prà della Rosa (WGS84: $45.8404^{\circ} \mathrm{N}$, $\left.10.7315^{\circ} \mathrm{E}\right)$, EU habitat 8210 Calcareous rocky slopes with chasmophytic vegetation, 1679 m a.s.1., 14 Aug 2020, V. Ghidotti (BS999; LSB).

\section{Germination data}

Pre-treatments: Seed surface sterilization in bleach $(10 \% \mathrm{v} / \mathrm{v}$ bleach solution, containing $0.1 \%$ Tween 20 surfactant) for 5 minutes followed by several rinses in sterilized distilled water.

Germination medium: agar $7 \mathrm{~g} \mathrm{~L}^{-1}$, sucrose $20 \mathrm{~g} \mathrm{~L}^{-1}$, Murashige and Skoog salts $2.15 \mathrm{~g} \mathrm{~L}^{-}$ 1 (i.e., applied at half-strength with respect to the original formulation), activated carbon $0.5 \mathrm{~g} \mathrm{~L}^{-1}, \mathrm{GA}_{3} 250 \mathrm{mg} \mathrm{L}^{-1}$ (added after autoclaving via cold filter sterilization).

Sample size: 1170 seeds $(\mathrm{n}=25)$.

\begin{tabular}{ccccccc}
\hline Germination & Thermoperiod & $\begin{array}{c}\text { Photoperiod } \\
\text { [light/dark] }\end{array}$ & $\mathbf{T}_{\mathbf{1}}$ [d] & $\begin{array}{c}\mathbf{T}_{\mathbf{5 0}} \\
\text { [d] }\end{array}$ & $\mathbf{T}_{\max }$ [d] & $\begin{array}{c}\text { MTG } \\
\text { [d] }\end{array}$ \\
\hline $\mathbf{8 2 . 8 \%}$ & alternating $22 / 10^{\circ} \mathrm{C}$ & $16 / 8 \mathrm{~h}$ & 16.0 & 27.0 & 49.0 & 31.2 \\
\hline
\end{tabular}

\section{Observations}

Addition of sucrose and half-strength Murashige \& Skoog (MS) medium was performed because the work aimed to encourage seedling growth after germination in order to produce plants for conservation activities (also for the other species studied here). A relatively low concentration of agar was used because this creates a less solid gel, minimizing surface tension and maximizing contact between the substrate and seeds, but providing enough solidity to support them at the air/substrate interface. 
Seed of this species has previously been germinated at high $\mathrm{G}$ values $(>90 \%$; Cerabolini \& al. 2004), for a population at the edge of the distributional range of the species (at Monte Barro regional park, Lecco). Here, the protocol is applied to a population from a different territory, aiming to produce plants to eventually reinforce the extremely small population at Monte Barro (Fig. 1B). Cerabolini \& al. (2004) recommended a concentration of $100 \mathrm{mg} \mathrm{L}^{-1} \mathrm{GA}_{3}$. However, we conducted an initial study using this concentration, which resulted in only $20 \%$ germination for the study population (data not shown). Thus, we decided to use a higher concentration, which resulted in the final germination rate $>80 \%$, and eventually the successful production of plants (Fig. 1B).

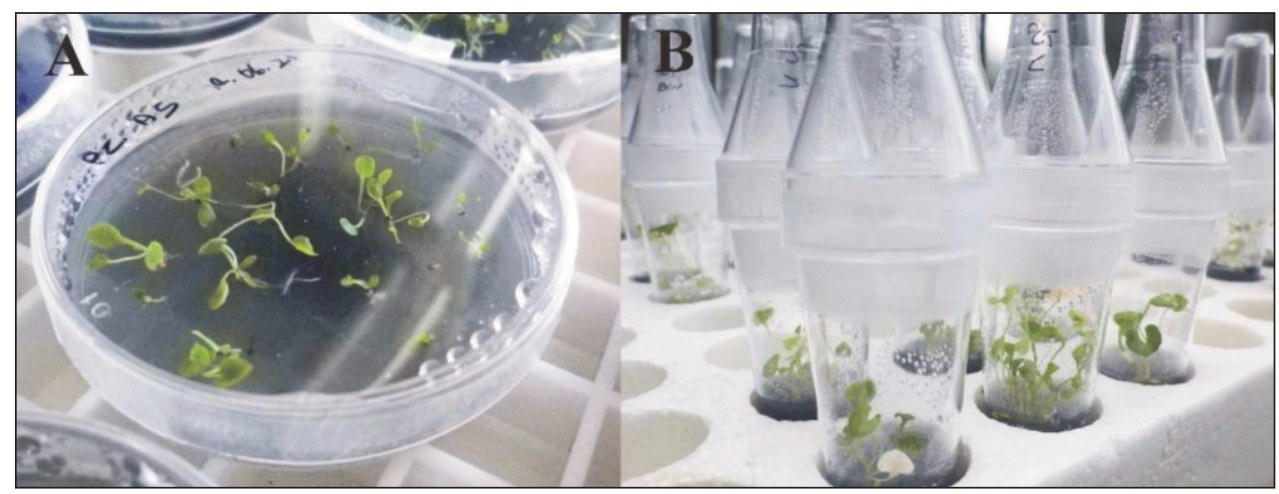

Fig. 1. Seedlings of Physoplexis comosa (A) at $32 \mathrm{~d}$ from sowing in a $5.5 \mathrm{~cm} \varnothing$ Petri dish, and (B) transferred to De Wit tubes at $122 \mathrm{~d}$ (Photos J. Bellingardi).

67. Primula glaucescens Moretti (Primulaceae) (Fig. 2)

\section{Accession data}

It: $\quad$ Monte Arera (BG), loc. Sentiero dei Fiori (WGS84: $45.927014^{\circ} \mathrm{N}, 9.802821^{\circ} \mathrm{E}$ ), EU habitat 6170 Alpine and subalpine calcareous grasslands, $1939 \mathrm{~m}$ a.s.1., 20 Aug 2019, R. M. Ceriani (BG975; Lombardy Seed Bank), 8 Sept 2008, Università di Pavia (BG840; LSB), Università di Pavia, 18 Sept 2004 (BG336; LSB).

\section{Germination data}

Pre-treatments: Seed surface sterilization in bleach $(10 \% \mathrm{v} / \mathrm{v}$ bleach solution, containing $0.1 \%$ Tween 20 surfactant) for 10 minutes followed by several rinses in sterilized distilled water.

Germination medium: agar $7 \mathrm{~g} \mathrm{~L}^{-1}$, sucrose $20 \mathrm{~g} \mathrm{~L}^{-1}$, Murashige and Skoog salts $2.15 \mathrm{~g} \mathrm{~L}^{-}$ ${ }^{1}$ (half-strength), activated carbon $0.5 \mathrm{~g} \mathrm{~L}^{-1}, \mathrm{GA}_{3} 100 \mathrm{mg} \mathrm{L}^{-1}$ (added after autoclaving via cold filter sterilization).

Sample size: 351 seeds $(\mathrm{n}=8 \times$ each seed lot). 


\begin{tabular}{|c|c|c|c|c|c|c|c|}
\hline Germination & Thermoperiod & $\begin{array}{l}\text { Photoperiod } \\
\text { [light/dark] }\end{array}$ & $\begin{array}{l}\mathbf{T}_{1} \\
{[\mathrm{~d}]}\end{array}$ & $\begin{array}{l}T_{50} \\
{[d]}\end{array}$ & $\begin{array}{c}T_{\max } \\
{[d]}\end{array}$ & $\begin{array}{l}\text { MTG } \\
\text { [d] }\end{array}$ & Seed lot \\
\hline $100.0 \%$ & alternating $22 / 10^{\circ} \mathrm{C}$ & $16 / 8 \mathrm{~h}$ & 3.5 & 10.9 & 21.0 & 13.3 & $\begin{array}{l}\text { BG336 } \\
\text { (2004) }\end{array}$ \\
\hline $98.5 \%$ & alternating $22 / 10^{\circ} \mathrm{C}$ & $16 / 8 \mathrm{~h}$ & 2.0 & 10.8 & 25.0 & 13.2 & $\begin{array}{l}\text { BG840 } \\
(2008)\end{array}$ \\
\hline $95.2 \%$ & alternating $22 / 10^{\circ} \mathrm{C}$ & $16 / 8 \mathrm{~h}$ & 1.0 & 8.8 & 14.0 & 13.7 & $\begin{array}{l}\text { BG975 } \\
(2019)\end{array}$ \\
\hline
\end{tabular}

\section{Observations}

Seeds of this species have previously been germinated in our laboratories with rates of up to $100 \%$ (Cerabolini \& al. 2004), but the present test provides valuable extra information because we found that high $\mathrm{G}(95-100 \%)$ was also evident for seed lots stored for up to 15 years at $-18^{\circ} \mathrm{C}$ in the seed bank (with no statistically significant difference between lots; ANOVA: F-ratio $=0.696, p=0.523$ ). This is a new and optimistic message for the seed banking of this species. Seeds were extremely resistant to long periods of surface sterilization, which were more effective at reducing contamination. Indeed, in a separate trial using only recently collected seeds with surface sterilization for 10, 20, 30 or 60 minutes, seeds in all treatments exhibited high germination $(79.6-89.3 \%)$ with no statistically significant differences evident (ANOVA: $\mathrm{F}=0.618, p=0.610$; data not shown). However, seeds treated for 10 to 20 minutes exhibited $25-38 \%$ contamination respectively, while seeds treated for 30 to 60 minutes were completely free of contamination (data not shown).

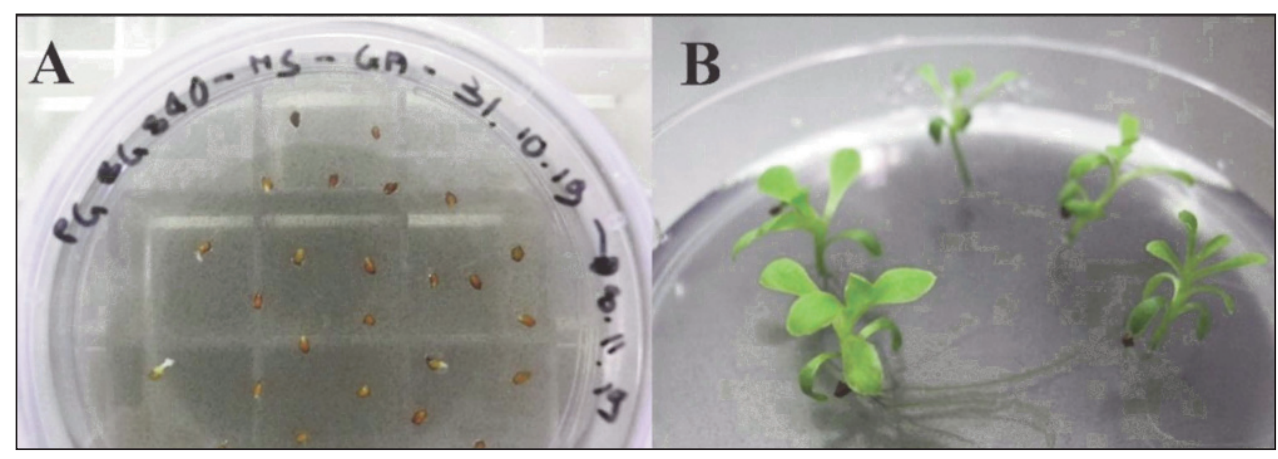

Fig. 2. Primula glaucescens (A) seeds germinating in a $5.5 \mathrm{~cm} \varnothing$ Petri dish, and (B). seedlings. (Photos J. Bellingardi).

68. Primula spectabilis Tratt. (Primulaceae) (Fig. 3)

\section{Accession data}

It: $\quad$ Dosso Alto (BS) (WGS84: $\left.45.806302^{\circ} \mathrm{N}, 10.407489^{\circ} \mathrm{E}\right)$, EU habitat 6170 Alpine and subalpine calcareous grasslands, 1754 m a.s.1., 09 Aug 2019, R. M. Ceriani (BS996; LSB). 


\section{Germination data}

Pre-treatments: Seed surface sterilization in bleach $(5 \% \mathrm{v} / \mathrm{v}$ bleach solution, containing $0.1 \%$ Tween 20 surfactant) for 60 minutes followed by several rinses in sterilized distilled water.

Germination medium: agar $7 \mathrm{~g} \mathrm{~L}^{-1}$, sucrose $20 \mathrm{~g} \mathrm{~L}^{-1}$, Murashige and Skoog salts $2.15 \mathrm{~g} \mathrm{~L}^{-}$ ${ }^{1}$ (half-strength), activated carbon $0.5 \mathrm{~g} \mathrm{~L}^{-1}, \mathrm{GA}_{3} 100 \mathrm{mg} \mathrm{L}^{-1}$ (added after autoclaving via cold filter sterilization).

Sample size: 807 seeds $(\mathrm{n}=8 \times 4$ treatments).

\begin{tabular}{ccccccc}
\hline Germination & Thermoperiod & $\begin{array}{c}\text { Photoperiod } \\
{[\text { light/dark] }}\end{array}$ & $\mathbf{T}_{\mathbf{1}}$ [d] & $\mathbf{T}_{\mathbf{5 0}}$ [d] & $\mathbf{T}_{\max }$ [d] & $\begin{array}{c}\text { MTG } \\
\text { [d] }\end{array}$ \\
\hline $\mathbf{9 5 . 4 \%}$ & alternating $22 / 10^{\circ} \mathrm{C}$ & $16 / 8 \mathrm{~h}$ & 8.0 & 12.3 & 30.0 & 14.7 \\
\hline
\end{tabular}

\section{Observations}

Initial germination trials were ruined by high rates of internal fungal contamination of surface-sterilized seed (data not shown). The present study determined that different exposure times to $5 \%$ bleach solution (4 treatments representing 10, 20, 30, 60 minutes of exposure) progressively and significantly diminished the contamination rate from $39.7 \pm 11.7 \%$ for the 10-minute exposure, to $8.4 \pm 2.8 \%$ for the 60 -minute exposure (ANOVA: $\mathrm{F}=1.292$, $p=0.296$; data not shown), while final germination rates were not significantly affected by bleach exposure times, ranging from $91.9 \pm 4.17 \%$ to $95.4 \pm 3.13 \%$ (ANOVA: $\mathrm{F}=0.106$, $p=0.955$; data not shown). (Indeed, the main $\mathrm{G}$ value reported here represents the mean value for the 60 -minute exposure time.) This suggests that fungal contamination was present throughout the seed coat, but not within the embryo.

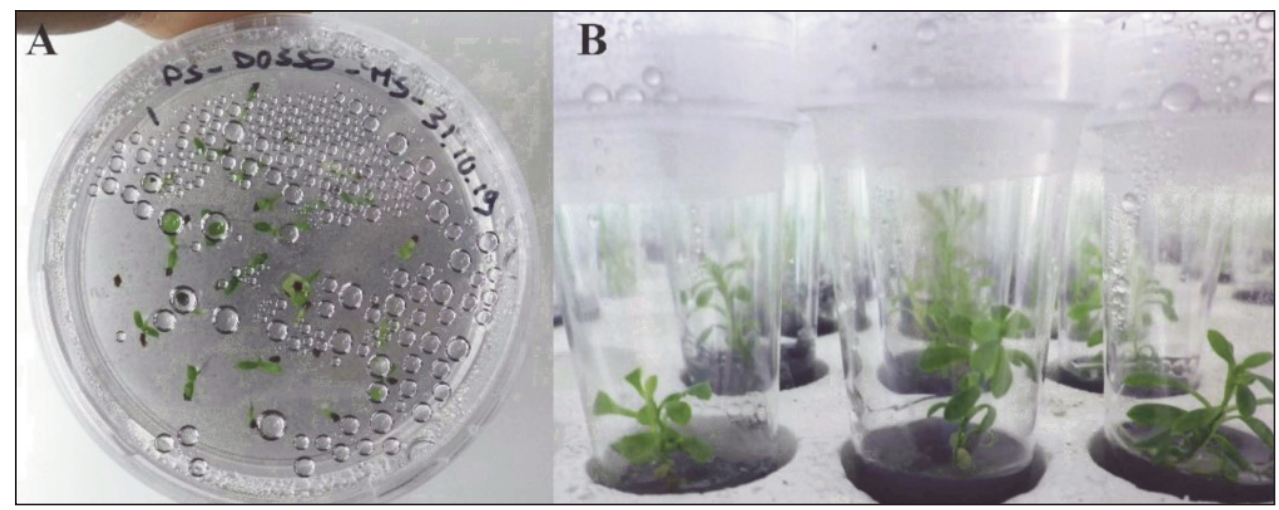

Fig.3. Primula spectabilis (A) seeds germinating at $5 \mathrm{~d}$ after sowing in a $5.5 \mathrm{~cm} \varnothing$ Petri dish, and (B) seedlings at $153 \mathrm{~d}$. (Photos J. Bellingardi). 
69. Spiranthes aestivalis (Poir.) Rich. (Orchidaceae) (Fig. 4)

\section{Accession data}

It: $\quad$ Soave $(\mathrm{MN})$, loc. Cascina Belvedere (WGS84: $\left.45.177087^{\circ} \mathrm{N}, 10.698333^{\circ} \mathrm{E}\right)$, population of 550 individuals in calcareous fen (EU habitat $7210^{*}$ Calcareous fens with Cladium mariscus and species of the Caricion davallianae), $17 \mathrm{~m}$ a.s.1., $23 \mathrm{Jul}$ 2020, S. Pierce (SP/0024/2020; all seeds from this lot were sown during the current experiments, and none were stored).

\section{Germination data}

Pre-treatments: Seed surface sterilization in bleach $(5 \% \mathrm{v} / \mathrm{v}$ bleach solution, containing $0.1 \%$ Tween 20 surfactant) for 5 minutes followed by several rinses in sterilized distilled water.

Germination medium: Malmgren (1996) terrestrial orchid medium (see Pierce \& Cerabolini 2011; Pierce \& al. 2015): agar $6 \mathrm{~g} \mathrm{~L}^{-1}$, sucrose $10 \mathrm{~g} \mathrm{~L}^{-1}$, activated charcoal powder $0.5 \mathrm{~g} \mathrm{~L}^{-1}, \mathrm{MgSO}_{4} \cdot 7 \mathrm{H}_{2} \mathrm{O} 75 \mathrm{mg} \mathrm{L}^{-1},(\mathrm{Ca})_{3} \mathrm{PO}_{4} 75 \mathrm{mg} \mathrm{L}^{-1}, \mathrm{KH}_{2} \mathrm{PO}_{4} 75 \mathrm{mg} \mathrm{L}-1, \mathrm{NH}_{4} \mathrm{NO}_{3}$ $100 \mathrm{mg} \mathrm{L}^{-1}, \mathrm{NH}_{4} \mathrm{H}_{2} \mathrm{PO}_{4} 150 \mathrm{mg} \mathrm{L}^{-1}$, modified by the addition of yeast extract $75 \mathrm{mg} \mathrm{L}^{-1}$, peptone $75 \mathrm{mg} \mathrm{L}^{-1}$ and $50 \mathrm{ml} \mathrm{L}^{-1}$ coconut milk. $\mathrm{pH}$ was adjusted to 5.8 using $0.1 \mathrm{~N} \mathrm{NaOH}$ or HCL immediately prior to autoclaving at $0.1 \mathrm{MPa}$ and $121^{\circ} \mathrm{C}$ for $20 \mathrm{~min}$.

Sample size: $\sim 12000$ seeds $(\mathrm{n}=60)$.

\begin{tabular}{ccccccc}
\hline Germination & Thermoperiod & $\begin{array}{c}\text { Photoperiod } \\
\text { [light/dark] }\end{array}$ & $\mathbf{T}_{\mathbf{1}}[\mathbf{d}]$ & $\mathbf{T}_{\mathbf{5 0}}[\mathbf{d}]$ & $\mathbf{T}_{\max }[\mathbf{d}]$ & MTG [d] \\
\hline $\mathbf{9 7 . 1 \%}$ & alternating $22 / 10^{\circ} \mathrm{C}$ & $0 / 24 \mathrm{~h}$ & 11.0 & 15.3 & 21.0 & 17.2 \\
\hline
\end{tabular}

\section{Observations}

Germination was denoted by swelling of protocorms accompanied by the production of rhizoids (Fig. 4A). A preliminary experiment comparing the modification of the substrate using coconut milk against a coconut milk-free control showed $100 \%$ germination in both groups, but further development of protocorms occurred only with the addition of coconut milk. Rarely for an orchid, seeds started germinating within the first two weeks of sowing (shown at $21 \mathrm{~d}$ in Fig. 4A). Over the first 70 days from sowing, protocorms elongated into long, thin tubers, 2-3 mm in length (Fig. 4B). At around 84 days, when tubers were 3.5-4 $\mathrm{mm}$ in length, the first true leaves developed at the distal extremity of the tuber (Fig. 4C). At this point plantlets were transferred into De Wit culture tubes on a fresh medium differing from the sowing medium only in a higher concentration of sucrose $\left(20 \mathrm{~g} \mathrm{~L}^{-1}\right)$; culture tubes were moved to a clean temperate greenhouse at ambient temperature and shaded from direct sunlight. By $174 \mathrm{~d}$ several plantlets had developed into green plants with 2 green leaves, and by $216 \mathrm{~d}$ plants with 4 true leaves were evident (Fig. 4D). 


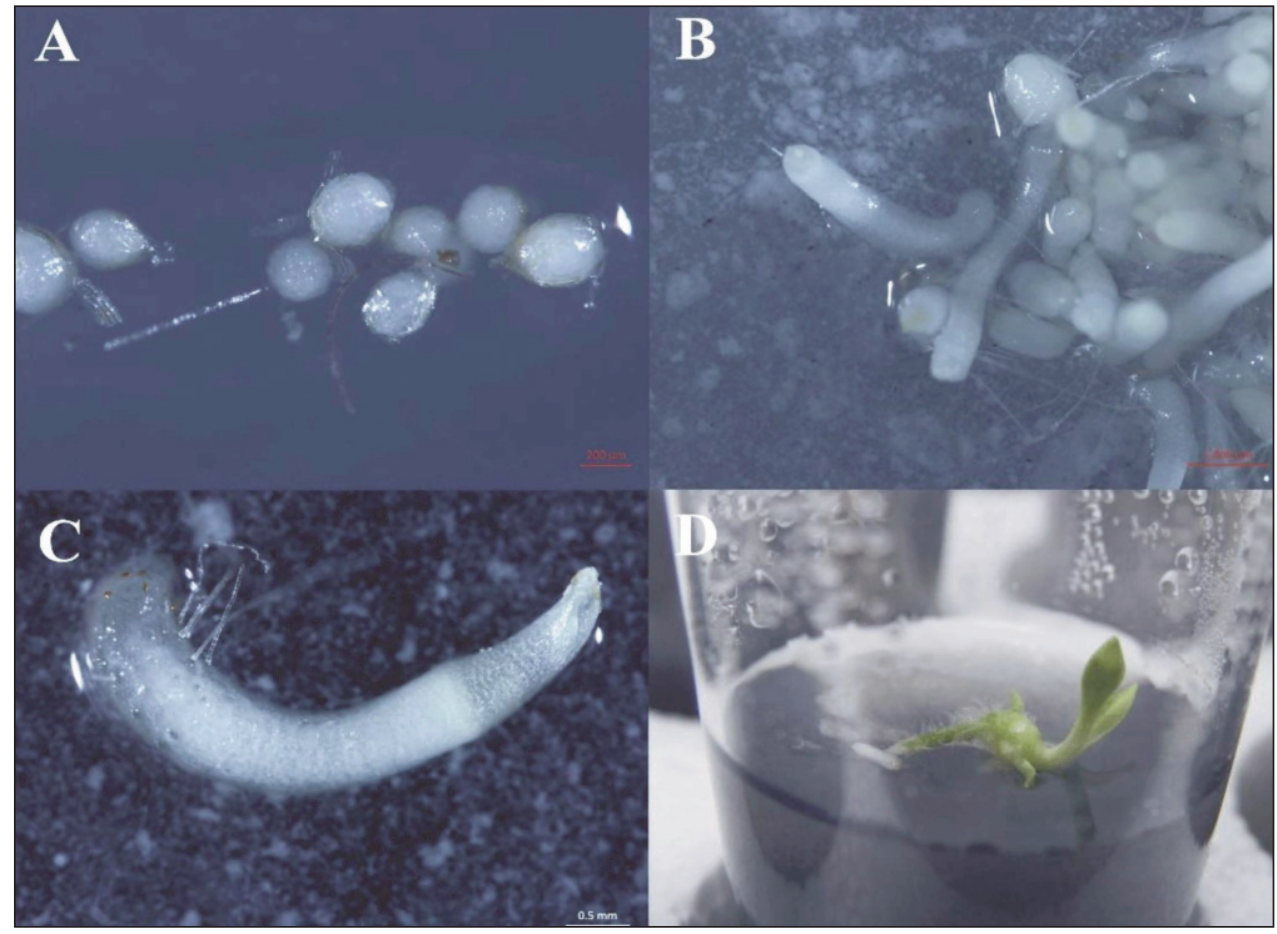

Fig. 4. Germinating seeds and plantlets of Spiranthes aestivalis at (A). 21 days after sowing, (B). 70 d, (C). 84 d, and (D). 216 d in a De Wit culture tube (photos by S. Pierce).

\section{Conclusions}

Germination percentages for Linaria tonzigii and Saxifraga tombeanensis were lower than $80 \%$, thus the related protocols are not presented here as for successful protocols of other species. Nonetheless, these species are extremely rare, classified as Endangered (IUCN), listed in Annex II of the EU Habitats Directive and populations of both are so small that collecting seed involves practical and ethical difficulties, and thus any information is valuable. Indeed, it is likely that germination percentages were low precisely because these species are so rare, due to the operation of Allee effects (genetic diversity is known at least for L. tonzigii to be extremely low; Biella \& al. 2021); germination rates of $>80 \%$ may be difficult to attain for these species. The following description of experiments is briefly presented in the hope that it will be valuable for future attempts to propagate these species.

For L. tonzigii, the global distribution of the species is limited to particular scree slopes within a $10 \mathrm{~km}^{2}$ area (accessibility problems also limit seed collection), and sufficient collectable seed is produced each year to allow only limited germination testing. Indeed, despite being careful to limit collection to only $20 \%$ of the fruits observed, it is likely that even single germination studies will have a significant impact on the reproductive capacity 
of the entire species, and testing must be conducted cautiously. Testing in previous years has determined that seeds require cold stratification and very high concentrations of $\mathrm{GA}_{3}$ to stimulate germination; germination ex situ does not occur without these conditions (Ferrario \& al. 2014).

We collected seeds from Pizzo Arera (BG) [loc. Corna Piana (WGS84: 45.92875 ${ }^{\circ}$, $9.616018^{\circ} \mathrm{E}$ ), EU habitat 8120 Calcareous and calcshist screes of the montane to alpine levels (Thlaspietea rotundifolii), 1960 m a.s.l., 20 Aug 2019, R. M. Ceriani (BG974; Lombardy Seed Bank-LSB); 31 Aug 2004, Università di Pavia (BG193; LSB)]. Seeds should be collected when the fruits are drying and opening naturally: plants must be checked every 7-15 days during August.

Seeds were cold-humid stratified at $4^{\circ} \mathrm{C}$ for 3 months $(86 \mathrm{~d})$ prior to sowing, wrapped in aluminium foil and placed in the refrigerator. Seeds were transferred to Petri dishes containing filter paper soaked in a solution of $250 \mathrm{mg} \mathrm{L}^{-1} \mathrm{GA}_{3}$ (pre-dissolved in 6 drops of $1 \mathrm{~N} \mathrm{NaOH}$ ), placed in the refrigerator for 48 hours. Seeds were surface-sterilized using a bleach solution $(5 \% \mathrm{v} / \mathrm{v}$ bleach solution, containing $0.1 \%$ Tween 20 surfactant) for 60 minutes followed by several rinses in sterilized distilled water. A range of Linaria species have been successfully germinated in vitro using either full-strength or halfstrength MS medium and low (<1\%) agar concentrations (e.g., Freipica \& Ievinsh 2010; Matveeva \& al. 2012; Pavlova \& al. 2014; Vladimirov \& al. 2018). Thus, the germination medium and environmental conditions (thermoperiod and photoperiod) follow the protocol for $P$. comosa, above.

Intriguingly, seeds stored for 15 years at $-18^{\circ} \mathrm{C}$ (seed lot BG193) showed germination percentages comparable to recently collected seeds (lot BG974; i.e. $58.5 \%$ cf. $46.8 \%$, respectively), indicating that longer-term storage for this species was not problematic. Germination of dark-coloured seeds was $21.5 \%$ greater than that of light seeds (for seed lot BG974; significantly different by $\mathrm{t}$-test; $\mathrm{t}=3.239, \mathrm{p}=0.0026$ ). The particularly low $\mathrm{G}$ of white seeds (an absolute value of $25.3 \%$ ) could reflect insufficient development at the time of capsule opening and seed dispersal. The reason for this is not known, but it is evident that ex situ production of plants should favour the use of dark-coloured seeds. Our germination tests led to the production of 300 seedlings which, at $48 \mathrm{~d}$, were transferred to De Wit tubes (substrate modified by substituting $\mathrm{GA}_{3}$ with $20 \mathrm{mg} \mathrm{L}^{-1}$ kinetin) for 6 months, then to a mixture of soil and Moregallo gravel (40:60), and cultivated in a temperate greenhouse.

For Saxifraga tombeanensis, seeds were collected during summer [from Cadria (BS) (WGS84: $45.781654^{\circ} \mathrm{N}, 10.642954^{\circ} \mathrm{E}$ ), EU habitat 8210 Calcareous rocky slopes with chasmophytic vegetation, $1210 \mathrm{~m}$ a.s.1., $17 \mathrm{Jul}$ 2019, S. Armiraglio (BS997; LSB) and from Corna Rossa (BS) (WGS84: $\left.45.800582^{\circ} \mathrm{N}, 10.614543^{\circ} \mathrm{E}\right), 1668 \mathrm{~m}$ a.s.1., 23 Jun 2020, S. Armiraglio (BS998; LSB)]. Seeds were surface sterilized and sown following the protocol and environmental conditions specified for P. comosa, above. Using lot BS998, pretreatment by surface sterilization of seeds with various combinations of bleach concentrations $(5$ or $10 \%)$ and exposure times $(5,10,15,30 \mathrm{~min})$ did not significantly affect germination or the extent of internal fungal contamination evident as hyphae growing from within seeds (ANOVA, $\mathrm{p}>0.05$; data not shown). The mean germination rate for BS998 was just $12.0 \%$. Maximum germination was $66.7 \%$ in a single replicate Petri of seed lot BS997 (the mean for this lot was $21.7 \%$ ). Seeds are extremely small (mean seed weight 
was $0.03 \mathrm{mg}$ ) and seedlings remain delicate, both above and below ground, during the first months of life. At 5 months from germination, some seedlings had not developed beyond the primary root plus cotyledon phase, some plants exhibiting true leaves but with underdeveloped root systems, and it is not clear if this is normal for the species. Note that additional testing using inositol to attempt further development of the root system did not significantly affect root system development or germination percentages (data not shown).

\section{References}

Armiraglio, S., Bertolli, A., Comini, B., Ghidotti, B., Prosser, F. \& Gentili, R. 2010: Saxifraga tombeanensis. The IUCN Red List of Threatened Species 2010: e.T161993A5524958. http://dx.doi.org/10.2305/IUCN.UK.2010-1.RLTS.T161993A5524958.en

Biella, P., Akter, A., Muñoz-Pajares, A.J., Federici, G., Galimberti, A., Jersáková, J., Labra, M., Mangili, F., Tommasi, N. \& Mangili, L. 2021: Investigating pollination strategies in disturbed habitats: the case of the narrow-endemic toadflax Linaria tonzigii (Plantaginaceae) on mountain screes. - Pl. Ecol. 222: 511-523. https://doi.org/10.1007/s11258-021-01123-7

Cerabolini, B., De Andreis, R., Ceriani, R. M., Pierce, S. \& Raimondi, B. 2004: Seed germination and conservation of endangered species from the Italian Alps: Physoplexis comosa and Primula glaucescens. - Biol. Conserv. 117: 351-356. https://doi.org/10.1016/j.biocon.2003.12.011

Ferrario, A., Pierce, S., Ceriani, R. M., Villa, M. \& Cerabolini, B. E. L. 2014: Germinazione, coltivazione su larga scala e rinforzamento della popolazione di Linaria tonzigii, una stenoendemica della Direttiva Habitat mai riprodotta prima. Poster presented at the $10^{\text {th }}$ National Congress on Biodiversity (Congresso Nazionale della Biodiversità), Rome, Italy 3 September 2014.

Freipica, I. \& Ievinsh, G. 2010: Relative $\mathrm{NaCl}$ tolerance of rare and endangered coastal plant species in conditions of tissue culture. - Environ. Exp. Biol. 8: 35-42. https://doi.org/10.22364/eeb

Jogan, N., Gargano, D., Montagnani, C. \& Bernhardt, K. G. 2013: Physoplexis comosa. The IUCN Red List of Threatened Species 2013: e.T162148A5549098. http://dx.doi.org/ 10.2305/IUCN.UK.2011-1.RLTS.T162148A5549098.en

Lasen, C., Bertolli, A. \& Prosser, F. 2013: Primula spectabilis. The IUCN Red List of Threatened Species 2013: e.T161891A5509776. http://dx.doi.org/10.2305/IUCN.UK.20111.RLTS.T161891A5509776.en

Malmgren, S. 1996: Orchid propagation. Theory and practice. - Pp.63-71 in: Allen, C. (ed.) North American native terrestrial orchids. Propagation and production. North American Terrestrial Orchid Conference Proceedings. - Germantown.

Mangili, F. \& Rinaldi, G. 2013: Linaria tonzigii. - The IUCN Red List of Threatened Species 2013: e.T162172A5553011. http://dx.doi.org/10.2305/IUCN.UK.2011-1.RLTS.T162172A5553011.en

Matveeva, T. V., Bogomaz, D. I., Pavlova, O. A., Nester, E. W. \& Lutova, L. A. 2012: Horizontal gene transfer from genus Agrobacterium to the plant Linaria in nature. - Mol. Plant Microbe Interact. 25(12): 1542-1551. https://doi.org/10.1094/MPMI-07-12-0169-R

Murashige, T. \& Skoog, F. 1962: A revised medium for rapid growth and bioassays with tobacco tissue cultures. - Physiol. Pl. 15: 473-497. https://doi.org/10.1111/j.1399-3054.1962.tb08052.x

Pierce, S. \& Cerabolini, B. E. L. 2011: Asymbiotic germination of the White Mountain Orchid (Pseudorchis albida) from immature seed on media enriched with complex organics or phytohormones. - Seed Sci. Technol. 39: 199-203. https://doi.org/10.15258/sst.2011.39.1.17

—, Guidi, V., Ferrario, A., Ceriani, R. M., Labra, M., Vagge, I. \& Cerabolini, B. E. L. 2015: Pea seed extracts stimulate germination of the terrestrial orchid Ophrys apifera Huds. during a habitat restoration project. - Pl. Biosyst. 149(1): 54-60. https://doi.org/ $10.1080 / 11263504.2013 .809814$ 
Vladimirov, I. A., Matveeva, T. V. \& Lutova, L. A. 2018: The method of transformation of Moroccan Toadflax (Linaria maroccana Hook. F.). - Russ. J. Genet. 54(8): 985-988. https://doi.org/10.1134/S1022795418080136

Addresses of the authors:

Simon Pierce ${ }^{1}$, Jessica Bellingardi ${ }^{2}$, Sara Villa ${ }^{1}$, Andrea Ferrario ${ }^{3}$, Stefano

Armiraglio $^{4}$, Bruno E. L. Cerabolini ${ }^{5}$, Roberta M. Ceriani ${ }^{2}$,

${ }^{1}$ Dipartimento di Scienze Agrarie e Ambientali - Produzione, Territorio,

Agroenergia (DiSAA), Università degli Studi di Milano, Via G. Celoria 2, 20133, Milano, Italy. E-mail: simon.pierce@unimi.it, sara.villa1@unimi.it.

${ }^{2}$ Centro Flora Autoctona; CFA, c/o Parco Monte Barro, via Bertarelli 11, I-23851, Galbiate, LC, Italy. E-mail: centroflora@parcobarro.it

${ }^{3}$ Studio F.A. Natura, via Fagnana 3/C, Turate (CO). E-mail:

fanatura14@gmail.com

${ }^{4}$ Municipality of Brescia - Museum of Natural Sciences, Via Ozanam 4, Brescia, Italy. E-mail: SArmiraglio@comune.brescia.it

${ }^{5}$ Dipartimento di Biotecnologie e Scienze della Vita (DBSV), Università degli

Studi dell'Insubria, via J.H. Dunant 3, 21100 Varese, Italy. E-mail: bruno.cerabolini@uninsubria.it 